\title{
Religiões institucionalizadas e universalistas e o mundo contemporâneo: quatro desafios - reflexões a partir da Igreja Católica
}

\author{
Leno Francisco Danner*
}

\section{Resumo}

Tematizam-se quatro desafios importantes postos pelo mundo contemporâneo às religiões institucionalizadas e universalistas: o desafio da autoridade e da legitimação do credo pela instituição religiosa; o desafio do controle institucional-religioso abrangente sobre gênero e sexualidade; o desafio do ceticismo em relação às fundamentações universalistas; e o desafio de um ecumenismo abrangente sem comprometimento com a afirmação e a imposição de um credo religioso em particular como base de uma possível integração cosmopolita. Ancorado nisso, defende-se que menos institucionalização e hierarquia, mais abertura democrática, abandono ou enfraquecimento dos controles sobre gênero e sexualidade, bem como, respeito à irredutibilidade das religiões entre si, o que implica moderação discursiva, poderiam servir como critérios normativos e programáticos para o fortalecimento das religiões neste início de século XXI enquanto instâncias basilares para a construção de uma sociabilidade mais justa, solidária e pacífica.

Palavras-chave: Religiões Institucionalizadas e Universalistas. Contemporaneidade. Pluralismo. Individualismo. Ceticismo.

\section{Institutionalized and universalist religions and the contemporary world: four challenges - some thoughts from Catholic Church}

\begin{abstract}
The article thematizes four important challenges of the contemporary world to institutionalized and universalist religions: the challenge of the institutional authority and legitimation of the creed; the challenge of the institutional-religious comprehensive control over gender and sexuality; the challenge of the skepticism concerning universalist
\end{abstract}

* Doutor em Filosofia. Professor de filosofia e de sociologia no Departamento de Filosofia da Universidade Federal de Rondônia (UNIR). E-mail: leno_danner@yahoo.com.br . 
foundations; and the challenge of a comprehensive ecumenism that is not committed with an affirmation and imposition of a particular religious creed as basis of a possible cosmopolitan integration. After this, the article defends that less institutionalization and hierarchy, more democratic openness, abandonment or weakening of controls over gender and sexuality, as well, as respect to irreducibility of religions to each other, which implies discursive moderation, could serve as normative and programmatic criterion to the strengthening of the religions in this beginning of XXI century as basic instances for the construction of a more just, fraternal, and peaceful sociability.

Key-words: Institutionalized and Universalist Religions. Contemporaneity. Pluralism. Individualism. Skepticism.

\section{Religiones institucionalizadas y universalistas y el mundo contemporáneo: quatro desafíos - reflexiones desde la Iglesia Católica}

\section{Resúmen}

Se tematiza cuatro desafíos importantes puestos por el mundo contemporáneo a las religiones institucionalizadas y universalistas: el desafío de la autoridad y de la legitimación del credo por la institución religiosa; el desafío del control institucional-religioso integral sobre género y sexualidad; el desafío del escepticismo en relación a las fundaciones universalistas; y el desafío de un ecumenismo integral sin comprometerse con la afirmación y la imposición de un credo religioso en particular como base de una posible integración cosmopolita. Con base en ello, se defiende que menos institucionalización y jerarquía, más apertura democrática, abandono o debilitamiento de los controles sobre género y sexualidad, así como respecto a la irreductibilidad de las religiones entre sí, lo que implica en moderación discursiva, podrían servir como criterios normativos y programáticos para el fortalecimiento de las religiones en este inicio del siglo XXI como instancias basilares para la construcción de una sociabilidad más justa, solidaria y pacífica. Palabras clave: Religiones Institucionalizadas y Universalistas. Contemporaneidad. Pluralismo. Individualismo. Escepticismo.

\section{Introdução}

O mundo contemporâneo não é um lugar inóspito às religiões e à religiosidade, de um modo geral, e às religiões institucionalizadas e universalistas, em particular. ${ }^{1}$ Se entendermos por contemporaneidade, como o farei ao longo do texto, a consolidação do pluralismo religioso-cultural e do individualismo

\footnotetext{
Por religiões institucionalizadas e universalistas significarei aquelas religiões calcadas na institucionalização do credo, que passa a ser legitimado a partir de procedimentos internos a essas instituições, e de matiz cosmopolita, isto é, cujo credo aponta para uma integração global ou universal com base nos princípios da religião em questão. Exemplos de religiões institucionalizadas e universalistas, nesse sentido que o estou utilizando, seriam o cristianismo, particularmente na vertente do catolicismo romano, e o islamismo. Neste texto, terei como base de meu diálogo a Igreja Católica.
} 
dos estilos de vida, correlatamente ao ceticismo em relação às fundamentações epistemológico-morais universalistas, podemos perceber que, de fato, tanto as religiões institucionalizadas quanto a religiosidade (espiritualidade) estão não apenas preservadas de uma excessiva racionalização (entendida como ênfase preponderante da ciência e da técnica em nossos modos de vida, de pensar, de fundamentar), inclusive não podendo ser deslegitimadas por essa mesma racionalização em excesso (própria de uma época tecnocientífica), mas também promovidas exatamente pela centralidade do pluralismo axiológico e do individualismo dos estilos de vida. Entretanto, é óbvio, como o reconheceu o próprio papa Francisco, ${ }^{2}$ que mudanças precisam ser feitas, ainda que gradualmente, no que tange à organização interna das religiões institucionalizadas e universalistas, bem como, ao contato com o público que elas levam a efeito.

Neste artigo, eu gostaria, tendo por base a força das religiões e da religiosidade enquanto núcleos importantes e inultrapassáveis da vida sociocultural contemporânea, de defender quatro argumentos centrais concernentes à relação entre religiões universalistas e a contemporaneidade. O primeiro diz respeito ao fato de que as religiões universalistas trabalham com uma noção forte de institucionalização, de autoridade e de dogma que implica a hierarquização da legitimação do credo, legitimação essa colocada por sobre as cabeças dos crentes e monopolizada por uma elite clerical, implicando, assim, a imposição como que direta deste aos crentes. Em relação a isso, argumento que a vida sociocultural contemporânea, marcada pelo crescente pluralismo religioso- cultural e pelo consolidado individualismo dos estilos de vida, leva a um confronto - geralmente caracterizado, ao nível das instituições religiosas, como perda da capacidade de influir no comportamento dos crentes e crescente ateísmo, bem como, ao nível da consciência individual, na perda da fé ou na desilusão ante as instituições religiosas - que exigirá das instituições religiosas abertura democrática e maior acolhimento pela secularização e liberdade individual, com menos institucionalização e menos hierarquia, de modo que essas instituições religiosas e suas elites clericais possam discutir fundamentações, práticas, valores e princípios teológicos com as comunidades de crentes e mesmo, em alguns casos, com os não crentes, enquanto ponto fundamental para o repensar e para a reconstrução tanto das próprias instituições religiosas quanto de sua vinculação social, política, cultural, epistemológica e normativa.

2 Cf.: http://g1.globo.com/mundo/noticia/2014/12/papa-diz-que-vaticano-sofre-de-alzheimer-espiritual.html. 
Meu segundo argumento, correlato ao primeiro, defende que as religiões universalistas possuem, em geral, uma tendência a controlar ou influir em todos os comportamentos dos crentes, particularmente, para o que me interessa aqui, nas questões de gênero e de sexualidade - são religiões universalistas não apenas no sentido de que se dirigem a todos, buscando aglutiná-los dentro de uma comunidade religioso-cultural homogênea, mas também no que diz respeito ao fato de que estabelecem um código de normas, práticas, valores e autoridades que incidem na e que buscam controlar a vida humana como um todo, tanto em nível intersubjetivo quanto em nível subjetivo, o que é uma consequência da assunção e da afirmação de bases, fundamentações, modelos e autoridades essencialistas e naturalizados, detentores de uma objetividade antropológico-ontológica, sociocultural e epistemológico-política forte, em muitos casos arredia às diferenças, insensível a estas. Ora, levando-se em conta o crescente pluralismo religioso-cultural e, mais ainda, esse consolidado individualismo dos estilos de vida, que conduzem a uma autonomia e a uma autodeterminação maiores por parte de cada indivíduo e mesmo de cada grupo social, afirmo que as religiões institucionalizadas teriam muito a ganhar se abandonassem ou se diminuíssem sensivelmente esses controles sobre gênero e sexualidade, que seriam, a partir de então, uma questão de decisão individual, orientada também pelo pluralismo axiológico, para não se falar de organização democrático-constitucional no que tange à convivência entre indivíduos e grupos plurais em uma sociedade democrática - inclusive, aqui, as religiões institucionalizadas e universalistas poderiam ajudar a combater o falocentrismo, o machismo, a homofobia e mesmo a excessiva moralização da sexualidade que elas contribuíram, em momentos anteriores, para instaurar.

Meu terceiro argumento consiste em tomar como ponto de partida o ceticismo contemporâneo acerca das fundamentações universalistas, decorrente do pluralismo religioso-cultural e do individualismo dos estilos de vida - o último ponto, na verdade, afeta também a compreensão de modernização calcada no modelo do racionalismo ocidental, que não consegue esconder seu papel colonizador, unidimensional e totalizante frente ao suposto não moderno. No caso das religiões institucionalizadas e universalistas, a noção de valores de verdade e de moralidade fortemente objetivos, bem como, de um projeto integrativo em nível cosmopolita ancorado na afirmação da religião, dá a tônica dos discursos e das práticas das instituições religiosas frente aos crentes e dessas instituições religiosas entre si. Ora, o mundo contemporâneo, se é bem verdade que por um lado não põe em xeque necessariamente 
a fundamentação epistemológico-moral universalista (o que implica que o relativismo e o ateísmo não impeçam esse mesmo universalismo e, no caso, a crença religiosa), por outro, na medida em que afirma a secularização, o pluralismo e a liberdade individual, exige mais uma vez procedimentos democráticos e moderação discursiva por parte das instituições religiosas (e mesmo das posições seculares e laicas frente às posições religiosas), de modo a que as diferenças não sejam simplesmente desconsideradas ou negadas pela tendência a uma objetividade axiológica forte, que esmaga as particularidades. Nesse sentido, um universalismo religioso, que é moderado, respeitador e inclusivo relativamente às diferenças, tem condições de, por um lado, assumir uma pretensão intersubjetiva de validade, com condições, inclusive, de vincular-se na esfera público-política e assumir o protagonismo nas discussões axiológicas cotidianas, na dinâmica das próprias instituições públicas, sem levar ao totalitarismo e ao fanatismo, por outro - pode-se ser universalista em termos religiosos, sob a forma de fundamentações essencialistas e naturalizadas, sem ser-se intolerante, negador das diferenças.

O quarto argumento, ligado ao anterior e desenvolvido em consonância com ele, consiste em que as religiões institucionalizadas e universalistas promovem a realização de um projeto ecumênico de alcance global, mas calcado na afirmação universalista ou cosmopolita de seus princípios internos, de modo a promover uma integração fundada na assunção do próprio credo a paradigma normativo e projeto societal. Além disso, esse projeto ecumênico geralmente tem por base a aglutinação dos grupos pertencentes ao mesmo credo religioso (mas dinamizados desde instituições diferentes - pense-se no cristianismo, representado por diferentes vertentes dele: catolicismo romano, luteranismo, anglicanismo etc.), de maneira a reduzir o projeto ecumênico, tão valioso do ponto de vista de uma relação global solidária, cooperativa e pacífica, a uma integração de uma mesma comunidade de crença, perdendo-se de vista o âmbito global de um modo mais geral. Esse âmbito global - a globalização cultural-econômica tem dramática e dolorosamente nos ensinado isso - já não aceita mais passivamente, se é que algum dia assim o fez, a imposição direta de uma forma de vida ocidental (capitalista, racional ou cristã) às custas da negação de outras formas religioso-culturais de vida. A globalização econômico-cultural é violenta e destruidora da diversidade por causa disso, isto é, por impor ideológica e militarmente uma forma de modernização (capitalismo, american way of life e racionalização) ao contexto global como um todo, incluindo os horizontes mítico-tradicionais, sem lhes dar voz e vez e, 
na verdade, destruindo-os paulatinamente. Desse modo, as religiões institucionalizadas e universalistas, como contraposição a esse modelo destrutivo e belicista de globalização econômico-cultural, poderiam encampar um projeto ecumênico moderado, sem pretensões colonizatórias, assimilacionistas e reducionistas (no sentido de afirmação e de imposição de uma posição religiosa em relação às demais), marcado pela cooperação, pela solidariedade e pela paz entre diferentes, diferentes que são irredutíveis uns aos outros (não necessitando, portanto, de uma concepção religioso-cultural homogeneizadora, mas sim apenas do respeito incondicionado à sua alteridade).

Não tenho dúvidas de que o futuro do século XXI, no que tange à paz e à solidariedade das sociedades democráticas e mesmo das relações mundiais, dependerá de como - e de quanto - as religiões institucionalizadas e universalistas se aproximarem de suas bases sociais, abrindo-se a processos democráticos no que tange à fundamentação de seus valores e de suas práticas. Também não tenho dúvidas de que o futuro das relações globais neste século XXI dependerá de como - e de quanto - as religiões institucionalizadas e universalistas dialogarem e cooperarem entre si sem pretensões de uniformização estrita, de afirmação da superioridade de um credo particular em relação a outros, e, portanto, tendo por base o respeito incondicionado à alteridade umas das outras. Como se pode perceber na Realpolitik hodierna, este início do século XXI, no que tange à globalização econômico-cultural, está sendo marcado pelo acirramento dos confrontos entre potências (de um lado, EUA e OTAN; de outro, Rússia e China; ou mesmo a guerra ao terror realizada desde o Ocidente contra países do Oriente Médio, cuja motivação básica é a conquista de posições políticas estratégicas e a manutenção de zonas de exploração econômica daquele contexto). Ou seja, conflitos violentos e possíveis guerras abrangentes poderão ser o resultado desse crescimento das hostilidades internacionais, motivadas basicamente por poder político e por dinheiro. Ora, as religiões institucionalizadas e universalistas, que não estão preocupadas nem com poder político nem com dinheiro, mas sim com a paz e com o amor, podem oferecer - elas e somente elas, que orientam a vida de pelo menos $90 \%$ da população mundial - um projeto ético-político alternativo à globalização econômico-cultural violenta e destruidora, negadora das diferenças.

Gostaria de tecer um último argumento. Ao longo do texto, falarei acerca das religiões institucionalizadas e universalistas em geral, a partir do entendimento de que elas são caracterizadas a) pela forte institucionalização em 
termos da construção, da interpretação, da legitimação e da imposição social do credo, de modo que a instituição religiosa, em linhas gerais, centraliza e monopoliza a constituição, a interpretação e o fomento social desse mesmo credo; b) pela afirmação de que o credo possui bases essencialistas e naturalizadas, que se sobrepõem ao pluralismo axiológico e ao individualismo dos estilos de vida, não sendo afetado - pelo menos não em seus fundamentos mais básicos - pelo ceticismo epistemológico-moral adveniente do relativismo cultural, do historicismo próprio às comunidades humanas etc., o que significa que esse mesmo credo, alicerçado em fundamentações essencialistas e naturalizadas, possui objetividade antropológico-ontológica, sociocultural e epistemológico-política forte, almejando exatamente o universalismo, isto é, a constituição de uma comunidade humana transcultural e trans-histórica, organizada em torno ao e dinamizada pelo credo religioso institucionalizado, no qual a instituição religiosa torna-se a arena, o caminho e o sujeito epistemológico-político fundamental, bem como, a orientação, em seus aspectos mais pormenorizados, sobre a vida humana como um todo (social e individualmente); e c) pela primazia da autoridade clerical em termos de centralização, de monopolização e de dinamização da constituição, da interpretação e do fomento social do credo, de modo que o sujeito epistemológico-político institucionalizado adquire centralidade e até se sobrepõe relativamente ao indivíduo comum quando a questão é a compreensão, a justificação e a validação do credo. Pois bem, essas são três características epistemológico-políticas e metodológico-programáticas das religiões institucionalizadas e universalistas em geral, com mais ou menos intensidade entre elas. Nesse sentido, mesmo que, ao longo do texto, minhas reflexões filosóficas girem fundamentalmente em torno da e tenham por base a análise da configuração institucional da Igreja Católica em particular, do catolicismo de um modo geral, creio e sustento que elas podem ser utilizadas para diferentes variantes religiosas, seja em termos do próprio cristianismo-catolicismo, como já citado, seja em termos do judaísmo, do islamismo, do budismo, do bramanismo etc. Conto, de todo modo, com a vênia do leitor no que diz respeito a esse conceito genérico de religiões institucionalizadas e universalistas.

\section{Fusão de culturas, subjetivação e erosão da autoridade}

Dois processos próprios da segunda metade do século XX, a gradativa democratização das sociedades ocidentais e a globalização econômico-cultural levada a efeito desde um modelo ocidental (racionalização, capitalismo, ame- 
rican way of life, belicismo), implicam correlatamente em uma transformação dos processos de socialização e de subjetivação que acontecem no seio das sociedades democráticas, bem como, a percepção que temos da própria globalização de um modo mais geral, tanto em seus aspectos normativos quanto em seus aspectos em termos de Realpolitik. A democratização das sociedades ocidentais, se é bem verdade que ainda possui falhas gritantes, necessitando de um longo caminho e de árduas lutas sociais e reformulações institucionais para tornar-se mais efetiva, levou à progressiva individualização dos estilos de vida e à consolidação do pluralismo religioso-cultural enquanto fenômenos concomitantes e centrais dessa realidade democrática contemporânea. Com efeito, são próprias das sociedades democráticas atuais a crescente individualização das escolhas e das práticas, já que o individualismo passa a ser uma de suas tendências mais fortes, bem como, a pluralização das posições religioso-culturais, que representa, metaforicamente falando, um verdadeiro mercado de ideias e de práticas as mais diversas, contraditórias ou complementares, as quais podemos nos apropriar seletivamente e sob a forma de diversas misturas.

Ou seja, as sociedades democráticas contemporâneas são cada vez mais pluralistas e individualistas, e esse é o fato basilar, conforme acredito e conforme desenvolverei mais adiante, para se entender alguns dos desafios colocados às religiões universalistas, que são institucionalizadas, hierárquicas e dogmáticas (no sentido de afirmarem uma fundamentação essencialista e naturalizada), monopolizando a compreensão dos textos sagrados e a legitimação do credo, possuindo um conceito forte de autoridade institucional, bem como, apontando para a realização de um projeto integrativo em nível cosmopolita. ${ }^{3}$ Como são sociedades democráticas cada vez mais individualistas, já não podem ser coordenadas nem guiadas em sentido estrito a partir de uma única autoridade religioso-cultural, assim como já não possuem uma autoridade central forte que determine de maneira férrea todas as ações individuais (o indivíduo contemporâneo enquanto contraposto, em grande medida, à autoridade); como são sociedades democráticas cada vez mais pluralistas, também não podem ser homogeneizadas nem integradas em sentido estrito a partir de uma única posição religioso-cultural, principalmente quando esta assume um embasamento essencialista e naturalizado, marcado por uma objetividade forte em termos antropológico-ontológicos, socioculturais e epistemológico-políticos. $\mathrm{Na}$ verdade, nessas mesmas sociedades democráticas, os processos de socia-

Utilizo o termo dogma no sentido de verdade fortemente objetiva, essencialista. 
lização e de subjetivação acontecem a partir de um processo que chamo de fusão de culturas, isto é, os indivíduos e os grupos sociais concomitantemente socializam-se e se subjetivam a partir da apropriação de valores e de práticas de diferentes - e às vezes divergentes - posições religioso-culturais, sem necessariamente assumirem um comprometimento ferrenho com uma delas em particular. Por exemplo, pode-se ser cristão e adepto do budismo ou da cabala, pode-se ser islamita e defensor do sexo livre, pode-se ser cristão ou islamita sem aceitar em sentido estrito a autoridade institucional e sem ir-se com frequência a uma igreja ou a uma mesquita etc.

Nesse contexto, os indivíduos e os grupos sociais formam-se a partir da apropriação seletiva de princípios e de práticas de várias posições religioso-culturais, em uma atitude vital eclética que rompe, em vários aspectos, com a pertença a comunidades de crença fechadas, fundamentalistas (no sentido de afirmação de uma verdade fortemente objetiva e essencialista) e arredias umas às outras. Ora, esses indivíduos e grupos, em seus processos de socialização e de subjetivação, não apenas se formam a partir da apropriação seletiva, como em um mercado de práticas e de valores, daquilo que consideram o melhor das posições religioso-culturais particulares (deixando de lado aquilo que, nelas, consideram defasado, arcaico ou não atual), mas também reprodurem esse processo de fusão de culturas ao longo do tempo, consolidando uma sociedade democrática em que efetivamente o pluralismo e o individualismo acabam dando a tônica dos processos de socialização e de subjetivação ali (nas sociedades democráticas) dinamizados, afetando diretamente as religiões universalistas institucionalizadas, hierárquicas e dogmáticas. As democracias contemporâneas, pluralistas e individualistas, ao serem marcadas por esse processo de fusão de culturas, permitem uma acentuada reflexividade, uma implacável crítica e uma atualização sem misericórdia das tradições religioso-culturais legadas, bem como, um generalizado enfraquecimento da autoridade das religiões universalistas no que tange à orientação estrita e geral de todos os comportamentos e de todos os estados de ânimo dos crentes.

Esse processo de fusão de culturas, decorrente da consolidação do pluralismo e do individualismo em termos de sociedades democráticas contemporâneas, rompe com o tipo de comunidade fechada que tradicionalmente demarcou os processos de socialização e de subjetivação das sociedades ocidentais (e mesmo mais além, ainda que em ritmo mais lento do que aqui) até o início do século XX. As comunidades fechadas seriam marcadas pelo fato de que, nelas, uma única posição religioso-cultural - ou, pelo menos, uma posição 
religioso-cultural hegemônica em relação às demais - regularia em sentido estrito os processos de socialização e de subjetivação, o que implicava no fato de que os indivíduos e os grupos sociais formavam-se a partir da inculcação desse credo religioso-cultural específico, geralmente em contraposição aos demais ou afirmado como o cerne da própria identidade individual e grupal, nacional inclusive etc. Nesse contexto tradicional, próprio das comunidades fechadas, a autoridade das instituições religioso-culturais permaneceria como que inquestionada, devido ao fato de ser monopolizada e dinamizada desde a instituição religiosa, hierárquica e verticalmente organizada, em que o credo oficial seria tanto interpretado e validado apenas internamente à instituição, por suas elites religiosas, quanto repassado aos crentes por sobre as cabeças destes e de modo dogmático. Comunidades fechadas seriam pouco individualizadas, haja vista o fato de que o credo religioso-cultural, assumindo um aspecto totalizante sobre os indivíduos e os grupos sociais, colocaria a autoridade e o dogma como as bases dos processos de subjetivação e de socialização, permitindo pouca liberdade e mobilidade individuais, principalmente em relação às próprias instituições legitimadoras do credo. Comunidades fechadas também seriam pouco pluralistas por causa da hegemonia social, política e cultural de um credo específico frente aos demais, que seria, desse modo, colocado como base das instituições públicas dessa mesma comunidade fechada, possibilitando pouco secularismo e laicismo, bases do pluralismo religioso-cultural e de sua afirmação política, sociocultural, jurídica e constitucional (cf.: DANNER, 2013a, p. 116-139).

Nas comunidades fechadas, de fundamentos epistemológico-culturais tradicionais, a autoridade institucional é forte, de efeitos abrangentes, e tem capacidade de gerar comportamentos e estados de ânimo coletivos efetivos e poderosos, influindo de maneira peremptória nos rumos dos processos de socialização e de subjetivação. Ao contrário disso, nas sociedades democráticas contemporâneas, a autoridade das instituições religioso-culturais já não consegue influir em todos os comportamentos dos crentes. As sociedades democráticas atuais, diga-se de passagem, são sociedades abertas pelo fato de que pressupõem o pluralismo religioso-cultural e uma forte individualização como base de sua dinâmica, em um processo de desencantamento do mundo (Max Weber) ou de linguistificação do sagrado (Jürgen Habermas), ou mesmo de pluralismo razoável (John Rawls), que inviabiliza a hegemonia de um único credo religioso-cultural em relação aos demais (cf.: RAWLS, 2000, 2002; HABERMAS, 2003; Weber, 1984a, 1984b, 1984c). As sociedades democráticas 
contemporâneas já não são mais comunidades (fechadas) em sentido estrito, posto que já não são mais determinadas por uma posição religioso-cultural específica, senão que por aquele processo de fusão de culturas (a partir do pluralismo e do individualismo) próprio delas. Nesse sentido, a autoridade de um modo geral e a autoridade religiosa em particular estão esfaceladas ou em crise permanente nas sociedades democráticas contemporâneas, devido tanto ao pluralismo religioso-cultural (que impede a hegemonia pública de uma posição religioso-cultural em relação às demais) quanto ao generalizado e consolidado individualismo dos estilos de vida, que coloca a liberdade individual como o fundamento inultrapassável das escolhas de valores e de práticas próprios à vida de cada um. É o indivíduo, e não mais a tradição, que se constitui no pilar de avaliação e de legitimação dos valores e das práticas das sociedades democráticas de um modo geral e das instituições e posições religioso-culturais em particular. Além disso, a consolidação do pluralismo religioso-cultural, enquanto base da cultura democrática contemporânea, inviabiliza uma autoridade religioso-cultural forte calcada na tradição, seja no horizonte público, seja no horizonte privado das próprias concepcỗes religioso-culturais (cf.: DANNER, 2013b, p. 275-312).

O que está em crise em relação à religião, hoje, portanto, no meu modo de entender, não é a religiosidade enquanto espiritualidade, mas sim a religião institucionalizada em sua constituição hierárquica, verticalizada e dogmática no que tange à interpretação dos textos sagrados, à legitimação e à validação do credo, bem como à imposição deste aos crentes. Nesse sentido, o que também está em crise é o tipo de autoridade institucional representado pelas religiões institucionalizadas e universalistas, autoridade essa que é validada internamente à instituição religiosa, pela elite eclesiástica, e que, voltando-se à regulação de todos os aspectos da vida individual e da dinâmica social, é imposta verticalmente aos crentes e não-crentes. No mesmo diapasão, outro ponto de crise relativamente às instituições religiosas universalistas diz respeito à afirmação, à legitimação e à imposição sociocultural e político-institucional de fundamentações essencialistas e naturalizadas de modo intransigente, sem qualquer moderação, uma vez que estas, por estabelecerem uma objetividade antropológico-ontológica, sociocultural e epistemológico-política forte, levam à negação das diferenças e, em particular, das minorias enquanto sujeitos público-políticos em igualdade de condições, ocasionando, em muitas situações, a exclusão, a marginalização e a deslegitimação dessas diferenças da esfera público-política, cultural e institucional. Primeiramente, há de se deixar claro 
que o pluralismo religioso-cultural e o individualismo dos estilos de vida não destroem as religiões institucionalizadas e universalistas em particular nem a religiosidade enquanto espiritualidade de um modo geral. Não destroem pelo fato de que, hoje, já estamos conscientes de que a racionalização tecnocientífica não resolve todos os problemas nem supre as lacunas de sentido que essa mesma racionalização teria deixado ao querer suplantar as religiões e a religiosidade. Por isso mesmo, é um equívoco afirmar-se que o pluralismo, o individualismo e até o ceticismo em relação às posições essencialistas e naturalizadas ponham em xeque a viabilidade destas, a dignidade destas, posto que é exatamente por causa do pluralismo e da liberdade individual, aliados à ausência de um poder sociocultural e político-institucional totalizante, unidimensional, massificador e absoluto, que se geram as condições políticas e a liberdade de crença, de pensamento, de associação. Sem esses princípios é que as religiões institucionalizadas e universalistas estariam em efetivo perigo - aliás, sem pluralismo, liberdade e relativismo-ceticismo moderado, forma alguma de vida seria possível ao longo do tempo.

$\mathrm{Na}$ contemporaneidade, portanto, estamos conscientes de que, para muitos indivíduos e grupos, só racionalização não é o suficiente para uma vida com sentido, mas também estamos conscientes de que as religiões e as religiosidades são elementos existenciais fundamentais para nos salvar do irracionalismo causado pela própria racionalização, para nos livrar das patologias psicossociais ocasionadas pela crescente tecnificação, burocratização e instrumentalização das estruturas, das práticas e dos valores sociais, inclusive servindo para refrear essa tendência intensificada atualmente de mais e mais racionalização (principalmente em termos de ciência e de técnica). Nesse mesmo diapasão, o pluralismo religioso-cultural e o individualismo dos estilos de vida também enfraqueceram as pretensões absolutistas da ciência e da técnica, deslegitimando como ilusória a associação entre razão e emancipação, e entre religião e obscurantismo, de modo que as religiões e as religiosidades puderam com justiça recuperar seu lugar importante e inultrapassável, como venho dizendo, para uma vida plena por parte dos indivíduos e dos grupos que efetivamente colocam uma posição religiosa ou a religiosidade como cerne de suas vidas.

Entretanto, há uma evidente crise de autoridade que perpassa a relação entre as religiões institucionalizadas e universalistas, de um lado, e, de outro, os crentes. As instituições religiosas, de sua parte, monopolizam a interpretação das Escrituras Sagradas em sentido estrito, impondo tal intepretação por sobre 
as cabeças dos crentes e não aceitando uma participação mais incisiva destes no que tange à discussão e à validação do credo. As instituições religiosas possuem uma hierarquia em termos de poder e de mando que monopoliza a legitimação do credo nos estratos mais elevados, entre suas elites eclesiásticas, de maneira a colocar a hierarquia como a base da dinâmica de validação do credo e de evolução religiosa, que, desse modo, ficam restringidas ao topo da pirâmide eclesiástica, como prerrogativa exclusiva desta. Por fim, as religiões institucionalizadas possuem uma noção forte de autoridade que, monopolizada por essa elite eclesiástica, fecha-se a uma sensibilização mais incisiva, seja desde os estratos menos poderosos entre sua hierarquia interna, seja, mais ainda, desde fora, por parte dos crentes. Por exemplo, um padre ou uma irmã religiosa dificilmente possuem poder de discussão e de decisão frente a um bispo ou a um cardeal. Da mesma forma, um crente possui pouca ou nenhuma legitimidade, em relação a um padre, um bispo ou um cardeal, no que tange a instaurar ou a repensar determinada interpretação ou prática religiosa. Além disso, essa autoridade forte se reflete no fato de que, tendo sua legitimação e evolução monopolizadas dentro da instituição religiosa e de acordo com sua hierarquia verticalizada, há uma imposição direta e às vezes intransigente do credo ao público, sem uma mediação que possa ouvir e atender aos anseios populares por renovação ou mesmo por algo mais simples, a saber, pela escuta de todos aqueles que não se sentem representados ou abarcados pela elite eclesiástica e pelo credo religioso. Tanto fora da instituição religiosa, entre o público de crentes e de não-crentes, quanto dentro da instituição religiosa, entre as elites eclesiásticas, a legitimação do credo e a autoridade institucional aparecem como dogmáticas, autorreferenciais e técnicas, pouco abertas a discussões e reformulações mais radicais, como se tais transformações pudessem destruir a integridade do credo e o poder da instituição religiosa no que tange à fundamentação desse mesmo credo.

As religiões institucionalizadas e universalistas possuem autoridade dogmática neste duplo aspecto: centralização e monopolização da legitimação do credo pela elite eclesiástica, organizada hierárquica e verticalmente; imposição direta e verticalizada desse credo ao público de crentes e de não crentes, de modo que, legitimado desde a dinâmica interna da instituição religiosa, ele assume ao público o caráter de algo inquestionável e basicamente impositivo (e também afirma-se desse modo), de verdade como que absoluta, à qual só resta a aceitação resignada como a melhor opção. Note-se, porém, que o consolidado individualismo dos estilos de vida e o forte pluralismo religioso- 
-cultural, próprios das sociedades democráticas hodiernas, já não aceitam mais esse tipo de instituição religiosa que centraliza a interpretação estrita do credo em uma elite eclesiástica que, desde dentro da instituição, o legitima e o impõe ao público de crentes e de não crentes. Nem os crentes não aceitam todas as imposições, assim como questionam uma monopolização estrita do credo dentro da instituição religiosa, nem os não-crentes aceitam facilmente uma intromissão maior das instituições religiosas quando se trata de questões políticas, jurídicas e constitucionais, nas quais o secularismo e a liberdade individual deveriam, segundo os não crentes, dar a tônica exclusiva ou preponderante (cf.: DANNER, 2011, p. 139-141).

As instituições religiosas, portanto, perdem a capacidade de influírem em todos os comportamentos dos crentes, bem como, perdem gradativamente a capacidade de, apenas a partir de sua dinâmica interna, validarem todos os princípios de seu credo religioso. Existem certas coisas que os indivíduos e os grupos sociais procuram experienciar de acordo com sua própria liberdade crítica e criativa. Por exemplo, indivíduos creem em Deus e seguem certos ritos próprios às instituições religiosas, mas usam anticonceptivos, casam-se e se separam, e tornam a casar-se e a separar-se, sem que isso (na sua percepção) prejudique ou diminua sua religiosidade e seu amor pela instituição religiosa etc. Note-se, nesse exemplo, que os indivíduos e os grupos continuam sendo religiosos, continuam possuindo religiosidade, mas não assumem todos os códigos religiosos nem aceitam uma regulação totalizante, por parte de uma instituição religiosa, sobre suas vidas. É isso o que significa a afirmação, que fiz, de que a instituição religiosa e sua autoridade enfraqueceram no que tange tanto à capacidade de monopolizar a interpretação do credo e sua veiculação ao público quanto à sua possibilidade de regular todos os aspectos da vida dos crentes (e até dos não crentes). Ora, isso nos permite perceber que mediações se fazem necessárias para que possa haver um processo mais efetivo de interação entre as instituições religiosas e o público em geral, afinal, como venho dizendo, não há qualquer contraposição entre as instituições religiosas e o público, assim como não há contraposição estrita alguma entre as religiões institucionalizadas e o pluralismo e o individualismo - apenas a necessidade de mediações, de reformulações mútuas, de aclimatações novas.

Menos institucionalização, menos hierarquia e menos autoridade, por parte das instituições religiosas, conforme penso, poderiam resolver esse problema que perpassa a relação entre as religiões institucionalizadas, hierárquica e dogmaticamente constituídas, e os consolidados individualismo dos estilos 
de vida e pluralismo religioso-cultural das sociedades democráticas contemporâneas. Menos ênfase em fundamentações essencialistas e naturalizadas, com sua aplicação eminentemente técnica, verticalizada e direta à sociedade de um modo geral, e mais moderação institucional e acolhimento das diferenças poderiam fortalecer a vinculação sociopolítica e o impacto cultural das religiões institucionalizadas, refreando sua tendência a um institucionalismo e a uma objetividade fortes que perdem qualquer ancoragem à realidade, uma vez tornando-se cegos ao pluralismo, às diferenças como base e condição não apenas da esfera público-política, mas da própria democracia, da própria sociabilidade de um modo geral. Isso significa que as instituições religiosas poderiam ouvir mais as vozes e atender mais às reivindicações dos crentes e mesmo dos não-crentes, em uma postura de abertura e de atenção que certamente tocariam os corações deles. É claro que as instituições religiosas não precisariam ceder em tudo e abandonar toda a sua autoridade no que tange à legitimação do credo e à inculcação deste junto ao público de crentes e de não crentes. Mas elas poderiam ser sensíveis ao fato de que o mundo contemporâneo, por ser extremamente pluralista e individualista, simplesmente não pode mais ser enquadrado de maneira simplista dentro de um modelo de socialização e de subjetivação calcado na autoridade interna da instituição religiosa tanto em termos de legitimação do credo quanto no que se refere à inculcação desse mesmo credo aos indivíduos e grupos sociais. Nesse sentido, fundamentações essencialistas e naturalizadas, enquanto base das instituições religiosas universalistas, já não podem ser aplicadas indistinta, direta e verticalmente à sociedade como um todo, como se o religioso fosse um intérprete e um aplicador técnico delas, como se o credo tivesse de ser seguido à risca em todos os seus pontos, como se ele fosse um conjunto técnico de normas, de práticas e de interpretações que não admitem abertura, reformulação e inovação, sem qualquer consideração para com o pluralismo, para com as diferenças, sem qualquer moderação discursiva e sem qualquer enfraquecimento epistemológico. Na época do pluralismo e do individualismo, a moderação discursiva e a sensibilidade em termos de aplicação do credo, assim como a inclusão política frente às, das diferenças, são o único caminho e os únicos princípios que restam a todos nós, às religiões institucionalizadas e universalistas. Menos institucionalização, menos hierarquia e menos autoridade significam, por conseguinte, mais abertura democrática e mais moderação discursiva. As igrejas poderiam convocar seus fiéis e mesmo os não crentes para debates coletivos sobre questões envolvendo a relação entre religião e vida, religião e 
sociedade, instituição religiosa e crentes, elites eclesiásticas e crentes, inclusive para saber que tipo de interpretação do credo esse mesmo público de crentes e de não crentes proporia ou consideraria mais adequado etc.

Abertura democrática e moderação discursiva implicam que não se possa controlar tudo e mesmo falar sobre tudo; há coisas que dizem respeito apenas às escolhas individuais, assim como há coisas que devemos calar, pelo bem do pluralismo e da liberdade. Abertura democrática e moderação discursiva implicam, ainda, que as instituições religiosas cedam espaços de vida e de legitimação aos indivíduos e aos grupos sociais, abandonando, como consequência, certas questões controversas (a partir do viés de uma postura dogmática em termos de autoridade institucional, calcada em uma fundamentação essencialista e naturalizada), já que, como venho dizendo, não se pode controlar tudo e todos, assim como não se pode falar sobre tudo e todos. Certos valores e práticas são irredutivelmente responsabilidade individual ou fazem parte do arcabouço cultural de posições religioso-culturais totalmente diversas das nossas, o que significa que não podem nem ser reduzidas às nossas posições nem ser entendidas ou racionalizadas por estas. De mais a mais, certas questões culturais e políticas podem e devem ser tratadas a partir do próprio arcabouço jurídico, constitucional e normativo democrático, em que a secularização, o laicismo, o historicismo, o pluralismo e o individualismo representam os valores básicos - certas coisas são apenas políticas (portanto: profanas, não metafísicas, não essencialistas, não naturalizadas), e assim devem continuar sendo, para o bem da democracia. Nesse sentido, a autoridade religiosa poderia abdicar de uma monopolização estrita da legitimação do credo religioso, bem como de uma hierarquização tão verticalizada internamente a si mesma, abrindo espaço para que crentes e mesmo não-crentes possam discutir e decidir sobre práticas religiosas e posturas institucionais, assumindo, ainda, uma postura de inclusão político-cultural das diferenças nas instituições e na própria esfera público-política como sujeitos, práticas, relações e valores que merecem ser respeitados e promovidos, que têm condições de dizer, de fazer e de ensinar coisas muito úteis para todos nós. Eu citaria, inclusive, o exemplo do papa Francisco e sua opção pela humildade e pela simplicidade, assim como pelo diálogo com o público em geral (ele disse que mesmo os ateus, se fossem bons, iriam para o céu; também disse que os animais iriam para o céu). Ora, as pessoas querem ver as autoridades religiosas (e as autoridades políticas muito mais!) dando exemplo de virtude e de abertura ao diálogo e à democracia, respeitando e sendo sensíveis às diferenças, acolhendo-as e pro- 
Religiöes institucionalizadas e universalistas e o mundo contemporâneo: 101 quatro desafios - reflexões a partir da Igreja Católica

movendo-as em sua irredutibilidade. Estes são valores que, hoje mais do que nunca, precisam ser vividos intensamente pelas instituições de um modo geral (incluindo, aqui, as instituições público-políticas) e as instituições religiosas em particular, sob pena de um crescimento vertiginoso de sua deslegitimação frente ao público dos crentes e dos não-crentes, sob pena, inclusive, de um crescente ceticismo e de uma forte anomia social, tal como estamos vendo hoje em nosso país - são as instituições que, uma vez tornando-se corrompidas, antiéticas e totalitárias, geram essas posturas de ceticismo, de anomia e de perda da solidariedade social.

\section{Gênero e sexualidade na época do pluralismo e do indivi- dualismo}

Gênero e sexualidade são questões que, conforme penso, efetivamente foram afetadas pelas consolidadas e radicalizadas individualização dos estilos de vida e pluralização religioso-cultural próprias das sociedades contemporâneas, implicando na necessidade de reformulação dos discursos e das práticas das instituições religiosas concernentes a essas temáticas. Note-se, em primeiro lugar, que não é mais possível pensar-se gênero e sexualidade a partir de uma perspectiva essencialista e naturalizada pura e simplesmente, como se os seres humanos, enquanto espécie, tivessem nascido com órgãos e funções próprias, diferenciados a partir da posse de um corpo feminino ou masculino. Como consequência, nem o fato de o homem ter um pênis e a mulher ter uma vagina, com seus respectivos aparelhos reprodutores, pode definir o tipo de comportamento e de psique que cada indivíduo terá. Também há de se mencionar a construção sociocultural dos papéis de gênero e das posturas sexuais: as compreensões do que são masculino e feminino, de seus lugares, de suas características etc., retiram a suposta naturalidade que subjazeria às definições de gênero e de sexualidade, ou constroem múltiplas supostas naturalizações para as definições de gênero e de sexualidade, para o que é ser homem, mulher, homossexual, e assim por diante (cf.: BUTLER, 2003, p. 102-118; MOORE, 2009 , p. 19-30). Ora, mas por que não se pode, por causa do pluralismo religioso-cultural e do individualismo dos estilos de vida, normatizar-se gênero e sexualidade a partir do binômio masculino-feminino?

Porque o pluralismo religioso-cultural e o individualismo dos estilos de vida implicam que a vivência de gênero e de sexualidade - não estou falando em escolha de gênero e de sexualidade pelo fato de que não parece esse o caso: não nascemos e depois escolhemos gênero e sexualidade - seja uma questão 
de esfera privada de vida, a ser decidida, ao longo do tempo, pelos indivíduos, seus gostos, suas aspirações, seus ideais, em suma, pelo indivíduo em processo permanente de autoconstrução, de aprendizado, de maturação existencial. Ou seja, os desejos individuais dependem única e exclusivamente dos próprios posicionamentos pessoais, de modo que é a liberdade crítica e criativa de cada indivíduo que efetivamente normatiza em última instância sobre o modo como ele deseja viver gênero e sexualidade - falta-nos, e nunca mais teremos, uma concepção epistemológico-moral forte e essencialista o suficiente para servir como guarda-chuva normativo para a crítica e o enquadramento de todos os aspectos da vida individual, de todas as nuanças desta, de modo que gênero e sexualidade perdem a referência a um modelo normativo que, como disse, já não mais existe em seu aspecto universalista, essencialista (existem muitos modelos, nenhum superior nem inferior em relação aos outros). Para além da discussão acerca do que é ou não é natural em relação ao gênero e à sexualidade, temos também - e em primeira mão - de levar em conta essa importante conquista da cultura democrática contemporânea, que é a liberdade individual no que tange à própria subjetivação, para além de condicionamentos sociais estritos ou mesmo de posições religioso-culturais totalizantes. Nesse sentido, portanto, o individualismo dos estilos de vida e o pluralismo religioso-cultural levam a um duplo movimento em termos da dinâmica de socialização-subjetivação nas sociedades democráticas contemporâneas: correlatamente, instauram uma esfera de vida individual totalmente personalizada, que, se por um lado bebe no horizonte sociocultural mais amplo no qual emerge em termos de orientação, por outro institui exatamente o próprio escrutínio individual como a fonte primeira e última das escolhas e das posturas existenciais; e, ao mesmo tempo em que impedem uma concepção religioso-cultural de assumir uma função totalizante em relação a toda a evolução social, historicizam e contextualizam as posições religioso-culturais, de modo a perceber-se sua localização e, portanto, sua limitação no tempo e no espaço. Desse modo, a historicização e a politização das concepções religioso-institucionais e de suas fundamentações, valores, práticas, códigos e autoridades essencialistas e naturalizadas implicam diretamente na historicização, na politização e na culturalidade das questões de gênero e de sexualidade, o que significa que eles não são mais naturais-naturalizados em primeira mão, mas exatamente politizados, historicizados, culturalistas - não faria sentido, assim, enquadrá-los apenas nem estritamente a partir de fundamentações essencialistas e naturalizadas, como questões essencialistas e naturalizadas. Gênero e sexualidade - que são mais 
Religiöes institucionalizadas e universalistas e o mundo contemporâneo: 103 quatro desafios - reflexões a partir da Igreja Católica

que o corpo biológico - deixam de ser objetos, práticas e valores naturalizados e se tornam pura e simplesmente historicizados, culturalistas, politizados, profanos, abrindo espaço para a postura crítica e criativa dos indivíduos e dos grupos socioculturais relativamente a eles.

Com isso, as sociedades democráticas têm de conviver com um paradoxo que jamais será superado, senão pela valorização do pluralismo e do individualismo, bem como, pela aceitação da historicidade, culturalidade e politicidade das posições religioso-culturais, além da aceitação da centralidade do relativismo epistemológico-moral (que, argumento mais uma vez, não põem em xeque as religiões institucionalizadas e universalistas e suas fundamentações essencialistas e naturalizadas). Por um lado, perde-se a ideia de natureza humana ou de naturalização, no sentido de que não é possível estabelecer-se uma estrutura de natureza humana modelar (via ciência ou filosofia ou religião) que sirva não apenas como pressuposto metodológico para a pesquisa com - e em termos de - ciência e técnica, mas também que se constitua em padrão normativo para o enquadramento crítico-moral das formas existenciais assumidas pelos indivíduos e pelos grupos ao longo do tempo (cf.: RORTY, 2010, p. 13-17; VATTIMO, 2004, p. 08-16). Os indivíduos e os grupos, seus valores, suas práticas, suas relações, suas formas axiológico-existenciais modelares, suas autocompreensões, são fundamentalmente construções e autoconstruções localizadas histórico-culturalmente, de modo que suas compreensões, em não possuindo qualquer objetividade e neutralidade científica mínimas, não apresentando qualquer resquício de tecnicalidade-instrumentalidade (na ciência, o que é técnico garante objetividade inconteste), ou mesmo um padrão normativo universalista no que tange ao gênero e à sexualidade, precisam ser remetidas àquela localização histórico-cultural e percebidas em seu sentido político-politizante. Por outro lado, o fato de nos afirmarmos como construções e autoconstruções histórico-culturais levadas a efeito desde uma perspectiva política-politizante não implica tornar-se normativa ou paradigmática a cultura de origem, perdendo-se, com isso, a capacidade de crítica das tradições vividas. Pelo menos isso não é verdade para o contexto das sociedades democráticas contemporâneas, nas quais, se a noção de natureza humana ou de naturalização é posta em xeque por causa de um relativismo, de um culturalismo, de uma politização e de uma historicidade radicais, também não é suficiente a afirmação de um modelo cultural-religioso particular como base normativa para o regramento das formas de vida socioculturais e individuais desse mesmo contexto democrático. As sociedades democráticas 
contemporâneas são sociedades totalmente relativistas no que tange ao gênero e à sexualidade, totalmente historicistas, culturalistas e politizadas em relação a eles, pelo menos em termos de não possuírem mais uma base normativa de caráter universalista, naturalista ou essencialista que sirva como guarda-chuva normativo das práticas e dos valores de cada posição moral.

Nas sociedades democráticas atuais e mesmo quando analisamos o mundo globalizado de um modo mais geral, simplesmente não há a normatividade em geral, síntese de todas as normatividades particulares, assim como não há a forma de vida em geral enquanto síntese de todas as formas de vida particulares, isto é, não existe uma posição epistemológico-moral universalista que sirva como padrão para a crítica e o enquadramento dessas formas de vida particulares, que sirva, como já disse, como guarda-chuva normativo das diferenças (cf.: LYOTARD, 1999, p. 11). Não apenas não há esse padrão epistemológico-moral universalista, mas também o consolidado pluralismo religioso-cultural contemporâneo impede a emergência desse paradigma pelo fato de que descobrimos a absoluta autorreferencialidade de uma posição religioso-cultural ou moral em relação a si mesma. Nesse sentido, o máximo que podemos fazer consiste em perceber a - e a partir da - absoluta irredutibilidade das formas de vida e das posições morais entre si, que não permite uma homogeneização estrita entre as formas de vida, assim como não possibilita a racionalização das posições religioso-culturais e morais entre si, a partir da afirmação de uma delas em relação às demais. A irredutibilidade das diferenças entre si, das formas de vida e das posições morais entre si, dos indivíduos entre si, dos grupos entre si, por conseguinte, permite a - e leva à - moderação discursiva e à abertura democrática, assim como à inclusão política, cultural e moral de todos e entre todos.

Ora, se - por causa do radical historicismo, da escancarada politização e da localização cultural contextualizada disso que compreendemos genericamente por formas de vida - não há mais uma estrutura de natureza humana exemplar, essencialista e naturalizada, que serviria como padrão normativo para a crítica, o enquadramento e a orientação de um modelo idealizado de ser humano; e se, por causa do pluralismo, também não há uma concepção religioso-cultural hegemônica em relação às demais que possa assumir esse papel de paradigma normativo para a crítica, o enquadramento e a orientação, as religiões institucionalizadas e universalistas, que se baseiam ou na naturalização do gênero e da sexualidade, ou na sua dependência de uma criação-determinação divina, o que confere um caráter essencialista a gênero 
Religiöes institucionalizadas e universalistas e o mundo contemporâneo: 105 quatro desafios - reflexões a partir da Igreja Católica

e sexualidade, também perdem a capacidade de definir de uma vez por todas de modo estrito e exclusivo o que é correto e o que não é correto em termos de gênero e de sexualidade, assim como não conseguem mais determinar qual é o lugar próprio a cada gênero, para não se falar da própria vivência considerada exemplar da sexualidade (cf.: Compêndio Vaticano II, p. 195-204). Efetivamente, o discurso da criação, no que tange ao gênero e à sexualidade, esbarra, hodiernamente, na mudança avassaladora dos papéis e das vivências em torno a gênero e sexualidade: noções de família que não se coadunam mais, que não se enquadram mais na definição de família tradicional; a vivência descontrolada e libertina da sexualidade para além da castidade; o homossexualismo, o bissexualismo, o transexualismo etc., todos esses fatores implicam que a divisão binária homem-mulher e as relações normativas dali advenientes, os papéis sociais dali originados, bem como, as tendências moralizantes em torno à sexualidade dessa divisão binária e tudo o que é contrário a essa mesma tendência binária, estejam bastante defasados para enfrentar essas mesmas mudanças contemporâneas (e outras correlatas - casamento civil de pessoas do mesmo sexo, adoção de crianças por casais de mesmo sexo, educação nas escolas a partir da afirmação de mais gêneros, e não dessa lógica binária de gênero etc.) (cf.: DINIS, 2008, p. 477-492).

Além disso, se poderia fazer a seguinte pergunta: em que a afirmação de mais gêneros e a vivência livre da sexualidade, bem como, a mudança na estrutura da família, por causa deles, poderiam atrapalhar os processos de socialização e de subjetivação hodiernos? Em que a historicização, o culturalismo, a politização e o sentido profano de gênero e de sexualidade podem atrapalhar as relações sociais, os processos de socialização e de subjetivação na contemporaneidade, na democracia? É claro que o homossexualismo, o casamento de pessoas do mesmo sexo e a adoção de filhos por eles, bem como, a vivência livre da sexualidade, não causam mal algum nem à sociedade nem aos indivíduos. Muitos serão heterossexuais, outros tantos serão homossexuais, mas, em havendo respeito e acolhida mútuos, não haverá problema tanto em termos de reprodução dessa suposta natureza humana (um argumento bastante ingênuo dos detratores do homossexualismo) quanto no que se refere à felicidade individual, afinal poderemos desenvolver-nos de acordo com aquilo que consideramos mais adequado para cada um de nós e sempre conscientes de que as noções de gênero e de sexualidade são construções políticas, históricas e culturalistas, e não ossificações naturalizadas que adquirem uma objetividade e uma moralização fortes a um ponto de, em não sendo respeitadas e seguidas, 
destruírem qualquer possibilidade de sentido para a vida humana, para a vida dos indivíduos desviantes desse padrão essencialista e naturalizado. Ou seja, não há problema algum nem à evolução sociocultural nem às vidas individuais se gênero e sexualidade forem determinados prioritariamente pela postura crítico-criativa de cada indivíduo, sem a imposição ou vigência totalizante de uma concepção rígida e moralizante de gênero e de sexualidade; no mesmo sentido, não há problema algum nem às sociedades democráticas, nem às vidas individuais, nem à coesão dos grupos sociais e, em tudo isso, nem às instituições religiosas se gênero e sexualidade forem compreendidos não mais a partir de fundamentos e de noções essencialistas e naturalizados, mas sim como construções históricas, políticas, culturalistas e profanas, localizadas no espaço e no tempo e, por causa disso, mutáveis - em consequência, ao não serem naturalizados, gênero e sexualidade perdem o sentido de uma objetividade e de uma moralização fortes, a-históricas, apolíticas, transculturais, abrindo espaço para a vivência do pluralismo, da diferença relativamente a eles. De todo modo, as sociedades democráticas contemporâneas caminham a passos largos no sentido de desconstruir todas as visões totalizantes e moralizantes sobre gênero e sexualidade (na prática, já fazem isso de um modo bastante intensificado), haja vista tanto a consolidação do pluralismo religioso-cultural quanto do individualismo dos estilos de vida, que conduzem a um crescente ceticismo em relação às fundamentações objetivas, universalistas, porque essencialistas e naturalizadas. $\mathrm{Na}$ medida em que os sujeitos, as relações, as práticas e os valores não são mais embasados em fundamentações essencialistas e naturalizadas, sendo reconhecidos como históricos, culturais, profanos e políticos, a revisão crítica e criativa e a construção de novas relações, práticas e valores se tornam o núcleo dos processos de socialização e de subjetivação, o núcleo da relação entre instituições e sociedade civil. Junto a isso, aquele processo, mencionado na primeira seção deste texto, de fusão de culturas aponta para uma postura seletiva, por parte dos indivíduos e dos grupos sociais, em relação aos valores e às práticas que eles consideram importantes de serem seguidos, ao passo que abandonam tudo aquilo que não consideram digno de ser vivido, em uma postura totalmente eclética e crítico-criativa em relação às posições religioso-culturais - gênero e sexualidade, hoje, portanto, dizem respeito cada vez mais à liberdade de cada indivíduo e grupo social tão-somente, sendo percebidos, enfatizo mais uma vez, basicamente como questões e construções relacionais, históricas, culturalistas, profanas e políticas, de modo a recusar-se sua compreensão essencialista e naturalizada (talvez o 
corpo tenha um sentido biológico, naturalizado e essencialista - embora ele também seja influenciado histórica, cultural e politicamente, sendo objeto de uma engenharia ético-estética por parte dos indivíduos e dos grupos sociais -, mas não mais gênero e sexualidade, que não se confundem mais com aquele).

No que se refere ao tratamento dado pelas religiões institucionalizadas e universalistas em relação às questões de gênero e de sexualidade, eu proponho o abandono ou pelo menos o relaxamento dos controles sobre gênero e sexualidade. No caso da Igreja Católica, para o que aqui me interessa, se poderia reformular o discurso sobre gênero em geral, evitando-se o binarismo homem-mulher, bem como, o machismo e o falocentrismo, a condenação religiosa e moral do homossexualismo, bem como, a excessiva moralização do sexo (para não se falar dos problemas ligados ao aborto, à eutanásia, à pesquisa científica com embriões humanos e ao uso de anticonceptivos etc.) (cf.: COLLINS, 2006, p. 05-48). Não há motivos para continuar-se com a afirmação teimosa, pouco atual e possivelmente geradora de preconceito e violência contra a alteridade, acerca do fato de que Deus criou homem e mulher destinados à procriação; também não há motivos para se continuar com as condenações, também constantes na Bíblia, de que homem não deve se deitar com homem, de que mulher não deve se deitar com mulher, para não se falar do sexo livre, do uso de anticonceptivos, do aborto e da eutanásia (aborto e eutanásia necessitam de uma discussão democrática mais secularizada, com menos pressuposições ligadas a uma noção de natureza humana essencialista ou de uma geração embasada em uma base religiosa); finalmente, não há sentido em associar-se, como fez o recente XIV Sínodo dos Bispos ${ }^{4}$ sobre a família no mundo contemporâneo, corpo biológico, órgão biológico e gênero e sexualidade, ligando, além do mais, biologia e teologia como interconectados e correlacionados etc. O pluralismo religioso-cultural, em sua radical historicidade e contextualização, nos ensinou que essas concepções arcaicas sobre gênero e sexualidade, de cunho essencialista e naturalizado, são parte de uma forma de vida entre outras, e de que hoje isso já não subsiste mais, de modo que gênero e sexualidade devem ser pensados a partir de seu sentido histórico, cultural e político no tempo e no espaço, recusando-se qualquer sentido transcultural, trans-histórico, apolítico e puramente naturalizado-biologicista em relação a eles. E a individualização dos estilos de vida nos tem ensinado que é a postura crítica e criativa de cada indivíduo e de cada grupo social

4 Cf.: http://www.vatican.va/roman_curia/synod/documents/rc_synod_doc_20151026_relazione-finale-xiv-assemblea_en.html 
que normatiza - ela e somente ela - sobre como eles querem ser e viver suas escolhas de gênero e de sexualidade.

Retirar ou refrear a normatização de gênero e de sexualidade, como exposta na Bíblia, permitiria à Igreja Católica um duplo sucesso: primeiro, evitaria as patologias psicossociais e toda uma ampla gama de violência prático-simbólica contra o feminino e, principalmente, contra o homossexualismo, que ainda se escora nas definições e nas condenações moral-religiosas supostamente fundadas na e fomentadas pela Bíblia, tendo em vista que uma grande dose de preconceito e de violência simbólico-prática contra as diferenças de gênero e de sexualidade baseia-se em interpretações fortemente objetivas desse livro religioso; segundo, permitiria, por parte da instituição religiosa e do público de crentes e de não-crentes, um referencial teórico-normativo de apoio às lutas por reconhecimento sociocultural e jurídico-constitucional, por igualdade e liberdade dos grupos marginalizados, das diferenças em geral (cf.: HONNETH, 2003, 2007). Permitiria, ainda, que os crentes homossexuais e feministas, por exemplo, pudessem sentir-se incluídos, respeitados e protegidos em suas escolhas, sem o sentimento de estar cometendo uma mácula por amar alguém do mesmo sexo ou por viver de maneira crítico-criativa sua sexualidade. Retirar ou refrear os controles sobre gênero e sexualidade, enfim, permitiria à Igreja uma postura extremamente atual e de apoio em relação às mudanças sofridas em termos dessas questões no mundo contemporâneo: tais mudanças são definitivas, não passageiras, e puseram por terra a hegemonia inconteste do binarismo de gênero e da moralização da sexualidade, com seu sentido essencialista e naturalizado-biologicista - incluindo, nos dois casos, casamento e adoção de filhos por parte de parelhas do mesmo sexo, aborto, uso de anticonceptivos, educação de gênero e sexualidade etc. Essa postura atual, conforme penso, permitiria, de um só golpe, enfrentar-se o preconceito e a violência contra as diferenças, e se promover essas mesmas diferenças em sua dignidade e em sua irredutibilidade, em uma espécie de correção de erros históricos contra as diferenças cometidos pelas instituições religiosas em geral e pela Igreja Católica em particular. Afinal, a influência desse tipo de atitude binária em relação ao gênero e de moralização da sexualidade ainda surte efeitos poderosos na constituição de uma cultura e de uma organização sociopolítica preconceituosas e violentas contra as diferenças. Combater isso é um dever imperioso por parte da Igreja Católica em particular, por parte das religiões institucionalizadas e universalistas de um modo geral, sua redenção enquanto instituições que se pretendem universalistas e enquanto religiões do amor incondicional e inclusivo. 
Religiöes institucionalizadas e universalistas e o mundo contemporâneo: 109 quatro desafios - reflexões a partir da Igreja Católica

\section{Ceticismo em relação às fundamentações universalistas e ecumenismo}

O pluralismo religioso-cultural e o individualismo dos estilos de vida, consolidados, como venho dizendo, enquanto bases das sociedades democráticas contemporâneas, bem como, a globalização econômico-cultural e suas contraditórias tentativas de uniformização econômica, cultural, política, epistemológica etc., escancaram outro fato inultrapassável do mundo hodierno, a saber, a crise das fundamentações universalistas e, assim, o ceticismo cada vez maior em relação à sua capacidade de, como paradigma epistemológico-moral e projeto integrativo cosmopolita, servirem para a crítica, o enquadramento e a mediação das relações entre contextos e culturas tão irredutíveis uns em relação aos outros. Ora, o que significa essa crise das fundamentações universalistas? Significa exatamente a impossibilidade, que podemos perceber hoje, de uma única posição religioso-cultural-moral servir como guarda-chuva normativo de todas as outras concepções religiosas, culturais e morais, de modo que, como consequência, temos o fim ou pelo menos uma limitação muito grande dos intentos epistemológico-morais universalistas e dos projetos integrativos cosmopolitas. Por outras palavras, não é possível a realização simplista de um paradigma epistemológico-moral universalista nem de um projeto integrativo cosmopolita que pudessem, dada sua generalidade, no primeiro caso, servir como concepção objetiva de normatividade que pudesse sustentar a crítica e o enquadramento dos contextos religioso-culturais particulares desde essa posição supostamente universalista, e, no segundo caso, aglutinar em uma mesma comunidade e em uma mesma identidade países, povos, culturas, religiões, religiosidades, moralidades etc.

Os projetos universalistas são caros, em primeiro lugar, à civilização ocidental de um modo geral e à Europa moderna em particular, haja vista que ambas colocam um ideal de civilização e de esclarecimento que se assume como representando todo o gênero humano, de modo a servir como guarda-chuva normativo crítico e protetor das particularidades, além de, correlatamente, projeto societal de alcance universalista (cf.: HABERMAS, 2012a, 2012b; FORST, 2010). Em segundo lugar, esses mesmos projetos universalistas são caros às religiões institucionalizadas e universalistas, como é o caso da Igreja Católica, como se pode perceber em duas passagens do Compêndio Vaticano II, a saber: "Enviada por Deus às nações para ser o 'sacramento universal da salvação', esforça-se a Igreja por anunciar o Evangelho a todos os homens" (Compêndio Vaticano II, p. 352; os grifos são do autor). E a outra passagem: “[...] a Igreja, 
sal da terra e luz do mundo, é chamada com mais instância a salvar e renovar toda criatura, para que tudo seja restaurado em Cristo, e n'Ele os homens constituam uma só familia e um só povo de Deus" (Compêndio Vaticano II, p. 352; os grifos do autor). Nessas passagens, pode-se perceber algo que, conforme venho dizendo, se assemelha muito aos ideais da civilização ocidental de um modo geral e da autocompreensão normativa que a modernidade europeia em particular (ambas forjadas e influenciadas indelevelmente pelo Cristianismo) têm de si mesmas: a possibilidade de fundamentação do universalismo epistemológico-moral e da realização de um projeto integrativo cosmopolita, enquanto dois momentos interdependentes, interligados (cf.: HABERMAS, 2004). A mesma intenção, ainda de acordo com as duas passagens do Compêndio Vaticano II, já citadas, faz parte dos anseios da Igreja Católica: a constituição de uma comunidade humana de identidade religiosa, integrada sob o Cristianismo e tendo a Igreja Católica como instituição legitimadora do credo e mesmo da integração, pelo menos em um aspecto muito poderoso.

Em que medida essas propostas de formulação de um paradigma epistemológico-moral universalista e de um projeto integrativo cosmopolita, seja de ordem racional, seja de ordem propriamente religiosa, podem ser sustentadas no mundo de hoje, marcado pelo avassalador pluralismo religioso-cultural e pelo consolidado individualismo dos estilos de vida, bem como, pelas tensões em termos de globalização econômico-cultural dinamizada desde o horizonte euronorcêntrico frente ao âmbito não-moderno, mítico-tradicional (e mesmo dentro do contexto ocidental - veja as tensões entre países desenvolvidos e países em desenvolvimento)? Se podem ser sustentadas, pelo menos em alguma medida, qual o tipo de discurso e de prática que deveriam ser instaurados não apenas dentro do nosso contexto, mas também em relação à interação com os demais contextos, diferentes do nosso? Ambas as perguntas querem apontar para o fato de que perdemos a capacidade de homogeneizar as diferenças, perdemos também a capacidade de construir uma identidade entre essas diferenças que pudesse apontar para um modo de vida ou para uma concepção religioso-cultural como superiores, como universalistas, de maneira a possibilitar exatamente tanto o paradigma epistemológico-moral universalista quanto o projeto integrativo cosmopolita - de todo modo, qualquer possibilidade de se construir essa identidade mínima passa exatamente pelo reconhecimento de que ela provavelmente não seja possível desde fundamentações essencialistas e naturalizadas, desde um ideal forte de objetividade antropológico-ontológica, sociocultural e epistemológico-política, mas sim pela moderação discursiva, 
pela inclusão política e pela sensibilidade na aplicação paradigmática. O pluralismo, o individualismo e a globalização econômico-cultural simplesmente nos mostraram que é impossível construir uma identidade comum entre países e povos, que é impossível colocar uma posição religioso-cultural ou uma forma de vida especificamente racional (segundo os moldes da ciência e da técnica ou de acordo com a imposição da forma de vida ocidental) como base para a crítica e para a integração universalistas - novamente: é impossível em termos de uma identidade forte e de sua imposição direta e verticalizada; impossível, ainda, sem abordar-se todas as consequências nefastas do colonialismo cultural, religioso, político, econômico, epistemológico etc. As diferenças serão sempre diferenças totalmente irredutíveis umas em relação às outras, nunca racionalizáveis, nunca homogeneizáveis, nunca redutíveis a um ponto de vista formalista e genérico - este é o ponto de partida para qualquer tentativa de fundamentação universalista e para qualquer projeto integrativo cosmopolita (cf.: HABERMAS, 2002; DANNER, 2014).

Esse é o ponto inultrapassável para qualquer posição normativa que se apresente como possuindo alcance universalista, a saber, as formas de vida religioso-culturais não são formalistas, mas sim práticas, nem podem ser reduzidas a uma análise formal exterior ao contexto em que elas são vividas. Formas de vida religioso-culturais não podem ser racionalizadas nem dissecadas em sua validade interna desde fora, desde paradigmas alheios aos contextos vitais dos quais aquelas formas de vida efetivamente emergem (e formas de vida sempre aparecem no singular) - como o faz erroneamente o racionalismo moderno em seu intento de servir como posição epistemológico-moral universalista, como guarda-chuva normativo das particularidades, como projeto integrativo cosmopolita. Conforme já dito, as diferenças serão, sempre e de modo irredutível, diferenças, não podendo ser nem assimiladas, nem integradas nem racionalizadas. A assimilação somente é possível por meio da violência simbólico-prática, que leva à negação de uma forma de vida por parte de outra forma de vida. Ora, nesse sentido, o que resta às posições epistemológico-morais universalistas, depois que esse mesmo universalismo comprovou-se como ilusão ou como tentativa fracassada de construção de uma concepção objetiva de normatividade e de realização de um projeto integrativo cosmopolita que sirvam para a crítica, o enquadramento e a homogeneização das particularidades?

Resta exatamente a abertura democrática, a limitação discursiva, o abandono de uma objetividade forte e o refreamento dos intentos universalistas, assim como a sensibilidade em termos de aplicação paradigmática. Com efeito, 
as posições universalistas já não podem mais buscar a todo custo a crítica e o enquadramento dos contextos religioso-culturais particulares com base em um suposto paradigma epistemológico-moral universalista, assim como já não podem mais buscar uma integração e homogeneização estritas de todos os contextos religioso-culturais particulares com base nos seus (das posições universalistas) princípios internos (cf.: CORBİ, 2012, p. 255-259; ROBLES, 2012, p. 193-200). Em primeiro lugar, não há uma forma de vida mais privilegiada ou mais madura ou mais universalista que as outras; em segundo lugar, como consequência, cada forma de vida tem igual direito de existência ou dignidade, por assim dizer, não podendo ser normativamente deslegitimada pelo fato de parecer menos racional ou menos universalista frente à nossa forma de vida ou a uma forma de vida considerada exemplar; em terceiro lugar, na medida em que são autorreferenciais, as formas de vida religioso-culturais possuem uma dinâmica interna própria que não apenas não pode ser violada desde fora, ainda que com base nesses supostos valores universalistas, senão que também não pode ser compreendida desde fora, de modo que não podem ser assimiladas e aglutinadas sob um mesmo guarda-chuva normativo ou a partir de uma forma de vida exterior.

Por causa disso, tanto o racionalismo ocidental quanto as religiões institucionalizadas e universalistas teriam muito a ganhar e a contribuir, em termos de resolução da globalização econômico-cultural desregulada e totalizante, bem como, da violência entre culturas e religiões por causa da colonização de umas sobre as outras, se abandonassem sua tendência à forte objetividade de seus princípios internos, objetividade forte que as leva a um discurso e a uma prática universalistas, que pressupõem um triplo problemático movimento: a afirmação de uma noção de verdade e de moralidade fortes, essencialistas, que conferem ao credo ou à forma de vida cultural em questão superioridade em relação aos outros credos e às outras formas de vida, possibilitando que aquele credo ou forma de vida superior possa servir como farol normativo e tábua de salvação (concebendo, correlatamente, os outros credos e as outras formas de vida como incapazes de servirem como farol normativo ou tábua de salvação); a aplicação paradigmática direta, verticalizada e sem mediação e sensibilidade dessa objetividade forte, dessa perspectiva essencialista e naturalizada frente ao pluralismo cotidiano, que geraria uma postura institucional unidimensional, massificadora e totalizante, que faria do sujeito epistemológico-político institucionalizado um técnico que decide, com base em seu credo-código autorreferencial (que somente esse técnico entende), o que é e o que não é 
objetivo, o que está e o que não está conforme à regra, quem se enquadra e quem não se enquadra no modelo essencialista e naturalizado hegemônico; e o fomento de uma prática missionária, messiânica e universalista que intenta um alcance cosmopolita, a criação de uma comunidade de crença homogênea, a partir daquele credo ou forma de vida considerada exemplar, universalista. Isso também carrega uma quarta pressuposição problemática, a saber, de que a instituição monopolizadora da legitimação do credo tenha o poder de orientar e de fundamentar tanto essa normatividade forte possibilitada pelo credo ou pela forma de vida exemplar quanto de orientar e de fundamentar o projeto integrativo cosmopolita, e isso de modo como que exclusivo, direto e sempre verticalizado.

Por que essas quatro pressuposições são problemáticas? Pelo fato de que, primeiramente, elas apontam para o fato de que a objetividade forte e essencialista ou o universalismo epistemológico-moral é a condição da existência das particularidades, a base normativa para a crítica, o enquadramento e a orientação dos contextos particulares, o farol a partir do qual essas particularidades são julgadas e guiadas. Com isso, elas apontam para a possibilidade de homogeneização estrita a partir de um credo ou de uma forma de vida em particular, para além das irredutíveis diferenças religioso-culturais entre as formas de vida, homogeneização estrita que é uma consequência direta dos projetos universalistas. Aqui começa a surgir o perigo da colonização violenta (e toda colonização é violenta) e da correlata negação de formas de vida religioso-culturais por meio da imposição cega e arbitrária de outras formas de vida. A história mais recente e o nosso contexto sociocultural e econômico-político atual estão carregados desses exemplos: guerras genocidas, violação às identidades culturais e religiosas sem fim, tudo isso em nome dessas tão afirmadas verdades fortemente objetivas que permitem a construção de faróis normativos, de paradigmas epistemológico-morais universalistas justificadores da crítica, do enquadramento e da integração das diferenças, de modo a também justificarem, como consequência, a prossecução totalizante e colonizatória do universalismo epistemológico-moral.

A abertura democrática, a moderação discursiva, o abandono de uma objetividade forte e o refreamento dos projetos universalistas permitiriam a sensibilização das práticas e dos valores das concepções universalistas de um modo geral e das religiões institucionalizadas e universalistas em particular para com as diferenças, na medida em que se as percebe como irredutíveis umas em relação às outras, bem como irredutíveis à nossa visão de mundo 
em especial. Isso faria justiça e daria o devido valor às diferenças, que geralmente, nas posições universalistas, têm seu valor diminuído ou negado por causa de uma noção forte de objetividade e por causa da afirmação do próprio universalismo epistemológico-moral como superior às particularidades. Nesse sentido, as religiões institucionalizadas e universalistas, uma vez refreando a objetividade forte de seus valores e a intensidade dos projetos universalistas, poderiam assumir uma postura de crítica e de enfrentamento em relação a todas aquelas tendências universalistas de caráter totalizante, como é o caso da globalização econômico-cultural atual, conduzida desde o horizonte euronorcêntrico, que visam assimilar e deslegitimar todos os contextos existentes com base em um suposto paradigma epistemológico-moral universalista e em um ideológico projeto integrativo cosmopolita, que nada mais fazem do que justificar a violência e a destruição causada pela globalização econômico-cultural em sua tendência incontrolável à racionalização, à reificação e à capitalização de tudo o que existe, animado ou inanimado, de tudo o que pode ser medido pelo dinheiro. As religiões institucionalizadas e universalistas, sensibilizadas desde essas transformações importantes do mundo contemporâneo, poderiam assumir o lugar da crítica e da emancipação outrora ocupado pela ciência e pela técnica, no que tange à realização de uma atitude de crítica e de enfraquecimento do universalismo epistemológico-moral (ou religioso-cultural, político-econômico etc.). As religiões, hoje, e não mais a ciência e a técnica, guardam e promovem a sensibilização sobre tudo o que existe - animado ou inanimado -, de modo que, em abertura democrática, moderação discursiva e sensibilidade às diferenças e à sua irredutibilidade, podem efetivamente promover uma mudança qualitativa nas relações humanas e entre seres humanos e meio ambiente. De todo modo, essa invectiva de moderação discursiva e sensibilidade em termos de aplicação paradigmática do credo por meio da instituição religiosa e de suas autoridades clericais é, hoje, o cerne do trabalho apostólico e pastoral do papa Francisco e em termos de Igreja Católica, citando nosso exemplo institucional referencial nesse texto. Com efeito, em sua recente encíclica Amoris Laetitia, o papa Francisco coloca exatamente a tensão entre fundamentação paradigmática e aplicação prática dessa mesma fundamentação como o núcleo duro da reflexão e da reconstrução da constituição e da atuação da Igreja Católica. Em um contexto marcado pelo pluralismo axiológico e pela individualização dos estilos de vida, essa correlação entre fundamentação e aplicação paradigmáticas não se dá mais de modo reto, direto e linear, não se dá mais de modo puro, por 
assim dizer. Por outras palavras, uma regra e uma prática, fundadas em bases essencialistas e naturalizadas, e sustentadas pela instituição religiosa em sua sobreposição ao cotidiano, já não podem mais ser impostas sem mediação ao pluralismo, exatamente porque ela não consegue abarcar a complexidade das situações encampadas por esse mesmo pluralismo. É assim que, na referida encíclica, a moderação discursiva, o discernimento institucional, a misericórdia e a gradualidade éticas e, finalmente, a sensibilidade em termos de aplicação do credo demarcam e devem demarcar, para o papa Francisco, a nova postura institucional e pastoral da igreja, tanto em sua constituição interna e em sua dinamização do credo por parte das autoridades eclesiásticas quanto na vinculação pública, política, social e cultural da Igreja e em sua utilização do credo para o enquadramento dos sujeitos, das relações, dos valores e das práticas cotidianos próprios ao pluralismo. Ele diz, em Amoris Laetitia:

Por isso, um pastor não pode sentir-se satisfeito apenas aplicando leis morais àqueles que vivem em situações "irregulares", como se fossem pedras que se atiram contra a vida das pessoas. É o caso dos corações fechados, que muitas vezes se escondem até por detrás dos ensinamentos da Igreja "para se sentar na Cátedra de Moisés e julgar, às vezes com superioridade e superficialidade, os casos difíceis e as famílias feridas" (PAPA FRANCISCO, 2017, \ 305, p. 244).

Trata-se, com isso, de se perceber o elemento mais básico cujo aprendizado nos é caso enquanto sociedades humanas, a saber, de que não há incompatibilidade entre objetividade e pluralismo, entre as diferenças e as instituições, entre o relativismo e as fundamentações essencialistas e naturalizadas: são apenas sujeitos, relações, práticas e valores múltiplos que conduzem para um mesmo fim, isto é, o engrandecimento e a plenificação dos seres humanos, que se dão de múltiplas formas, por vários caminhos. As instituições religiosas não apenas não são afeitas pelo pluralismo, como também podem aprender com ele, renovar-se com ele, andando de mãos dadas com as diferenças, protegendo-as, promovendo-as, integrando-as.

\section{Considerações finais}

O padre Roberto Francisco Daniel, conhecido como Pe. Beto, recentemente excomungado pela Igreja Católica por suas declarações favoráveis ao casamento entre pessoas do mesmo sexo, disse que igreja alguma é, hoje, a solução para os indivíduos e os grupos sociais em termos de sentido e de 
orientação vitais. ${ }^{5}$ Gianni Vattimo, por sua vez, na obra Depois da Cristandade: por um cristianismo não-religioso, interpreta o mandamento de Jesus Cristo do amor incondicional como implicando não na institucionalização e monopolização do credo por parte da Igreja Católica ou de qualquer igreja cristã de um modo mais geral, de acordo com suas regras internas e autoridade hierárquica e verticalmente concebidas, ancorado em uma fundamentação essencialista e naturalizada, mas sim na secularização, na pluralização e na individualização das escolhas e das práticas - amor como recusa da verdade fortemente objetiva e essencialista, monopolizada institucionalmente, amor como recusa do institucionalismo e de uma fundamentação essencialista e naturalizada do ser humano, amor como abertura, acolhimento e respeito às diferenças (cf.: VATTIMO, 2004, p. 35). Tanto na afirmação do Pe. Beto quanto na afirmação de Vattimo, portanto, a instituição religiosa é ou desnecessária ou supérflua ou até prejudicial - para a vivência da religiosidade e para a leitura dos textos considerados (pelas instituições religiosas) como sagrados. Mais do que isso, as religiões institucionalizadas poderiam desvirtuar e até prejudicar o alcance e o sentido revolucionário do amor, do respeito, da solidariedade, da cooperação, da alteridade etc., o que as tornaria um empecilho, e não uma fonte promotora, da sociabilidade e da autorrealização individual e social. Argumento que Pe. Beto e Vattimo têm razão nessas afirmações se as religiões institucionalizadas e universalistas mantiverem um fechamento teimoso contra o público de crentes e não crentes e contra as mudanças socioculturais e políticas do mundo contemporâneo, sustentando e promovendo sem sensibilidade uma postura de afirmação e de imposição de uma fundamentação essencialista e naturalizada que é cega e até contraposta às diferenças.

Porém, em havendo um rejuvenescimento por parte dessas mesmas instituições religiosas universalistas, elas se tornam não apenas atualizadas, democráticas e inclusivas, mas também absolutamente fundamentais, no plano político-cultural nacional e global, para a erradicação dos preconceitos e para a construção de um mundo mais justo, solidário, cooperativo e pacífico. Por isso a necessidade de menos institucionalização, menos hierarquia e menos dogmatismo, e mais abertura democrática e moderação discursiva, de mais sensibilidade paradigmática para com as diferenças, seu acolhimento, sua promoção, de modo a refrear seja a afirmação forte e essencialista de uma concepção normativa em particular, seja a intensidade dos projetos crítico-

5 Cf.: http://g1.globo.com/sp/bauru-marilia/noticia/2014/10/igreja-nenhuma-e-solucao-diz-padre-excomungado-em-bauru.html. 
Religiöes institucionalizadas e universalistas e o mundo contemporâneo: 117 quatro desafios - reflexões a partir da Igreja Católica

-integrativos universalistas frente às diferenças, diferenças que sempre serão irredutíveis. Isso me permitiria fazer alusão, como forma de conclusão deste texto, àquele que considero o mais importante distintivo da religiosidade cristã, a saber, o amor incondicional em relação às diferenças, colocado no mesmo patamar do amor ao próprio Deus. Amor incondicional é, fundamentalmente, reconhecimento da irredutibilidade das diferenças e, a partir disso, a realização da abertura democrática, da moderação discursiva, do refreamento da objetividade forte e essencialista dos valores, bem como da recusa ou da limitação dos projetos universalistas - amor como não-poder, recusa da afirmação do poder, como radical aceitação, acolhimento e respeito por todos e a todos. As religiões institucionalizadas e universalistas, nesse sentido, poderiam perceber que é exatamente nas diferenças irredutíveis que múltiplas formas de se chegar ao sagrado, à espiritualidade, e múltiplas compreensões desse mesmo sagrado e dessa mesma espiritualidade, bem como, no que tange às múltiplas formas de se viver o sagrado e a espiritualidade - mas somente isso -, podem possibilitar, se não essa base minimamente comum, o ponto de partida para uma postura de respeito e de acolhimento alegre e sincero das diferenças enquanto diferenças, mesmo que a nossa forma de vida religioso-cultural ou racional apareça, agora, como apenas mais uma em meio à multidão.

Nesse sentido, o pluralismo axiológico, o individualismo dos estilos de vida e o ceticismo epistemológico-moral relativamente aos projetos fundacionais e integrativos universalistas-cosmopolitas me permitem argumentar em favor de quatro questões importantes às religiões institucionalizadas e universalistas, seja em sua estruturação interna, seja no que diz respeito à sua vinculação e à sua atuação público-política. O primeiro deles consiste em que as sociedades contemporâneas deixaram de ser comunidades fechadas, de forte identidade cultural e étnica, de pouca individuação e de coordenação centralizada, por parte de uma ou de outra instituição religioso-cultural em particular, dos processos de socialização e de subjetivação. São sociedades abertas, altamente pluralistas e marcadas por uma individualização muito forte. Logo, também não se sustenta mais um modelo de instituição religiosa fechado, seletivo, excludente e autorreferencial e autossubsistente e autossuficiente, que, por isso mesmo, precisa tornar-se mais aberta, inclusiva, participativa e moderada, menos autorreferencial, autossubsistente, autossuficiente, endógena e autônoma e mais ligada ao cotidiano, em diálogo permanente com crentes e não crentes. $\mathrm{O}$ segundo deles, em consequência, consiste em que a interpretação do credo já não pode assumir um sentido fortemente objetivo 
em todos os aspectos nem uma imposição verticalizada e tecnicista acerca de todos os casos e sobre todos os sujeitos. Fazem-se necessários o diálogo com a sociedade, a percepção das diferenças e da realidade que elas colocam e, em tudo isso, a moderação discursiva e a sensibilidade paradigmática em termos de vinculação da instituição e do credo frente à sociedade civil. O terceiro deles consiste em que, pelo fato de o pluralismo cultural, o individualismo dos estilos de vida e o ceticismo axiológico colocarem a historicidade, o culturalismo e a politização como os valores-chave dos processos de socialização e de subjetivação, as religiões institucionalizadas e universalistas têm condições de uma visão mais realista do conjunto e do contexto representado pelo seu credo, podendo reformular ou mesmo abandonar certas partes dele. De fato, aqui, o credo não é, como um todo, eterno, imutável; há partes dele que são puramente culturais e que, enquanto tais, podem ser repensadas, reconstruídas, reformuladas ou até abandonadas sem prejuízo da integridade e da integralidade desse mesmo credo. O quarto deles e síntese dos demais, consequência dos demais, está em que, dados o pluralismo, o individualismo e o ceticismo, dados o culturalismo, a historicidade e a politização, a discussão acerca do credo não pode ser apenas técnica nem, em consequência, centralizada e monopolizada forte e exclusivamente na e pela elite clerical, a partir de um modelo de instituição autorreferencial, autossuficiente, autossubsistente, endógena e autônoma. Quanto mais democracia, inclusão e participação na construção do credo, tanto mais objetivo ele será, mais imune a degenerações ele será. Em suma, no contexto do mundo contemporâneo, plural, político, culturalista e histórico, a reformulação e o abandono de partes problemáticas do credo passam a ser, em minha compreensão, pontos-chave da constituição e da vinculação público-política das religiões institucionalizadas e universalistas, o que também significa que a abertura democrática, a moderação discursiva, a sensibilidade paradigmática e o enfraquecimento das fundamentações essencialistas e naturalizadas passam a ser a condição basilar para a reflexivização dessas mesmas instituições.

\section{Referências}

BUTLER, Judith. Problemas de Gênero: Feminismo e Subversão da Identidade. Tradução de Renato Aguiar. Rio de Janeiro: Civilização Brasileira, 2003.

COLLINS, John J. A Bíblia Justifica a Violência? Tradução de Walter Eduardo Lisboa. São Paulo: Paulinas, 2006. 


\section{Religiões institucionalizadas e universalistas e o mundo contemporâneo: \\ quatro desafios - reflexões a partir da Igreja Católica}

CONCÍLIO ECUMÊNICO VATICANO II. Compêndio Vaticano II: Constituições, Decretos, Declarações. Introdução e Índice Analítico de Frei Boaventura Kloppenburg. Petrópolis: Vozes, 1983.

CORBİ, María. "Elementos Constitutivos do Paradigma Pós-Religional”, Voices: Theological Journal of EATWOT, vol. XXXV, nº. I, jan./mar. 2012, p. 255-259, ISSN: 2222-0763.

DANNER, Leno Francisco. "Pensamento Metafísico e Pensamento Pós-Metafísico: a Propósito de Uma Distinção e Algumas Implicações”, Argumentos (UFC), nº. 06, p. 128-141, 2011. ISSN: 1984:4247.

"O Ethos Sociocultural Contemporâneo: das Culturas Tradicionais à Fusão de Culturas", Pensando - Revista de Filosofia (UFPI), vol. 4, nº. 8, 2013a, p. 116-139, ISSN: 2178-843x.

. "Um Fundamento para o Ecumenismo: a Irredutibilidade do Outro", Horizonte, ISSN 2175-5841, Belo Horizonte, v. 12, n. 33, jan./mar. 2014, p. 70-98.

"Notas sobre o Processo de Evolução Sociocultural Contemporâneo: da Fusão de Culturas à Erosão da Autoridade", Kalagatos - Revista de Filosofia, Fortaleza (CE), v. 1, nº 19, 2013b, p. 275-312, ISSN: 1984-9206.

DINIS, Nilson Fernandes. "Educação, Relações de Gênero e Diversidade Sexual”, Educação \& Sociedade (Campinas), vol. 29, no. 103, p. 477-492, 2008. ISSN: 0101-7330.

FORST, Rainer. Contextos da Justiça: Filosofia Política para além de Liberalismo e Comunitarismo. Tradução de Denilson Luís Werle. São Paulo: Boitempo, 2010.

HABERMAS, Jürgen. Teoria do Agir Comunicativo: Racionalidade da Ação e Racionalização Social (Vol. I). Tradução de Paulo Astor Soethe. Revisão Técnica de Flávio Beno Siebeneichler. São Paulo: Martins Fontes, 2012a.

. Teoria do Agir Comunicativo: sobre a Crítica da Razão Funcionalista (Vol. II). Tradução de Flávio Beno Siebeneichler. São Paulo: Martins Fontes, 2012b.

- A Inclusão do Outro: Estudos de Teoria Política. Tradução de George Sperber e de Paulo Astor Soethe. São Paulo: Loyola, 2002.

. Direito e Democracia: entre Facticidade e Validade (Vol. II). Tradução de Flávio Beno Siebeneichler. Rio de Janeiro: Tempo Brasileiro, 2003.

. A Ética da Discussão e a Questão da Verdade. Organização e Tradução de Patrick Savidan. Tradução de Marcelo Brandão Cipolla. São Paulo: Martins Fontes, 2004.

HONNETH, Axel. Luta por Reconhecimento: a Gramática Moral dos Conflitos Sociais. Tradução de Luiz Repa. São Paulo: Editora 34, 2003.

. Reificación: Un Estudio en la Teoría del Reconocimiento. Traducción de Graciela Calderón. Buenos Aires: Katz, 2007.

LYOTARD, Jean-François. La Diferencia. Traducción de Alberto L. Bixio. Barcelona: Editorial Gedisa, 1999.

MOORE, Henrietta L. Antropología y Feminismo. Traducción de Jerónima García Bonafé. Madrid: Ediciones Cátedra, 2009. 
PAPA FRANCISCO. Amoris Laetitia. Vaticano: Tipografia Vaticana, 2016. Disponível em: <http://www.agencia.ecclesia.pt/netimages/file/papa-francesco_esortazione-ap_20160319_ amoris-laetitia_po.pdf>. Acesso em: 28 mar. 2017.

RAWLS, John. Justiça e Democracia. Tradução de Irene Paternot. São Paulo: Martins Fontes, 2000.

. O Liberalismo Político. Tradução de Dinah de Abreu Azevedo. Brasília: Instituto Teotônio Vilela; São Paulo: Editora Ática, 2002.

ROBLES, José Amando. "Cambia Copernicanamente la Religión. Deve Cambiar la Teología", Voices: Theological Journal of EATWOT, vol. XXXV, n. I, jan./mar. 2012, p. 193-200, ISSN: 2222-0763.

RORTY, Richard. Uma Ética Laica. Tradução de Mirella Traversin Martino. São Paulo: Martins Fontes, 2010.

SYNOD OF BISHOPS. XIV Ordinary Assembly. "The Vocation of the Family in the Church and in the Contemporary World." The Final Report of the Synod of Bishops to the Holy Father, Pope Francis. Accessed: 27/12/2016. In: http://www.vatican.va/roman_curia/synod/ documents/rc_synod_doc_20151026_relazione-finale-xiv-assemblea_en.html

VATTIMO, Gianni. Depois da Cristandade: por Um Cristianismo não Religioso. Tradução de Cynthia Marques. Rio de Janeiro: Editora Record, 2004.

WEBER, Max. Ensaios sobre Sociología de la Religión (T. 1). Madrid: Taurus, 1984a.

WEBER, Max. Ensaios sobre Sociología de la Religión (T. 2). Madrid: Taurus, 1984b.

WEBER, Max. Ensaios sobre Sociología de la Religión (T. 3). Madrid: Taurus, 1984c.

Submetido em: 29-11-2016

Aceito em:16-4-2018 